\title{
慢性関節リウマチ滑膜病態形成における ケモカインと接着分子のクロストーク
}

\author{
田中良哉*
}

\section{review article}

\section{JAPANESE JOURNAL OF INFLAMMATION}

Crosstalking between chemokines and adhesion molecules in the pathogenesis of rheumatoid arthritis

Rheumatoid arthritis (RA) is characterized by marked infiltration of the synovium by $\mathrm{T}$ cells. The mediator of joint inflammation has been shown to be both cellular and soluble mediated by multiple cytokines including chemokines. The concept of the crosstalking between adhesion molecules and cytokines and its relevance to inflammation is emerging.

Expression and function of adhesion molecules are tightly regulated via intracytoplasmic signaling induced by cytokine or chemokine stimulation, which process is designated "inside-out signal". Such a regulation is most emphasized with inflammatory processes, in which $\mathrm{T}$ cells migrate from circulation into the tissue. $\mathrm{T}$ cell migration depends on integrin-mediated adhesion to endothelial ligands. Endothelial cells in RA synovium characteristically express heparan sulfate proteoglycan, which is involved in $\mathrm{T}$ cell integrin-triggering by "posting" chemokines, produced from synovial T cells, and by "relaying" them to their receptors on $\mathrm{T}$ cells which activate G-protein-dependent PI 3-kinase and actin-dependent integrin-triggering.

Adhesion molecules not only function as a glue but also transduce extracellular information into cytoplasmic organelle through "outside-in signal", resulting in cell activation and cytokine production. For instance, the abundant ICAM-1 and CD 44 on RA synoviocytes not only potentially facilitate interaction to $\mathrm{T}$ cells or extracellular matrix but induce cytokine gene transcription in synoviocytes via nuclear factor activation.

Taken together, the busy two directional crosstalking among adhesion molecules and cytokines appears to be significant for the initiation and prolongation of inflammatory processes through $\mathrm{T}$ cell migration into RA synovial tissues and activation of both $\mathrm{T}$ cells and synovial cells there.

Rec. 2/2/2000, pp 107 117

Yoshiya Tanaka*

key words : adhesion, integrin, chemokine, rheumatoid arthritis, signal

* The First Department of Internal Medicine, School of Medicine, University of Occupational and Environmental Health, Japan 産業医科大学医学部第一内科学教室 Offprint requests to: Yoshiya Tanaka, The First Department of Internal Medicine, School of Medicine, University of Occupational and Environmental Health, Japan, 1-1 Iseigaoka, Yahata-nishi, Kitakyushu, 8078555 Japan
慢性関節リウマチ (rheumatoid arthritis；RA) は, 関節を病変の主座とする原因不明の全身性炎 症性疾患であるが，発熱や全身倦怠感などの全身 症状や, 肺などの関節外臓器の症状を伴うことも ある。関節滑膜では, 血管新生, $\mathrm{T}$ 細胞の浸潤と 活性化, 滑膜細胞の増殖を中心とする急性ないし 慢性の滑膜炎症が展開し, 炎症性肉芽組織(パンヌ 
vascular Iunmen

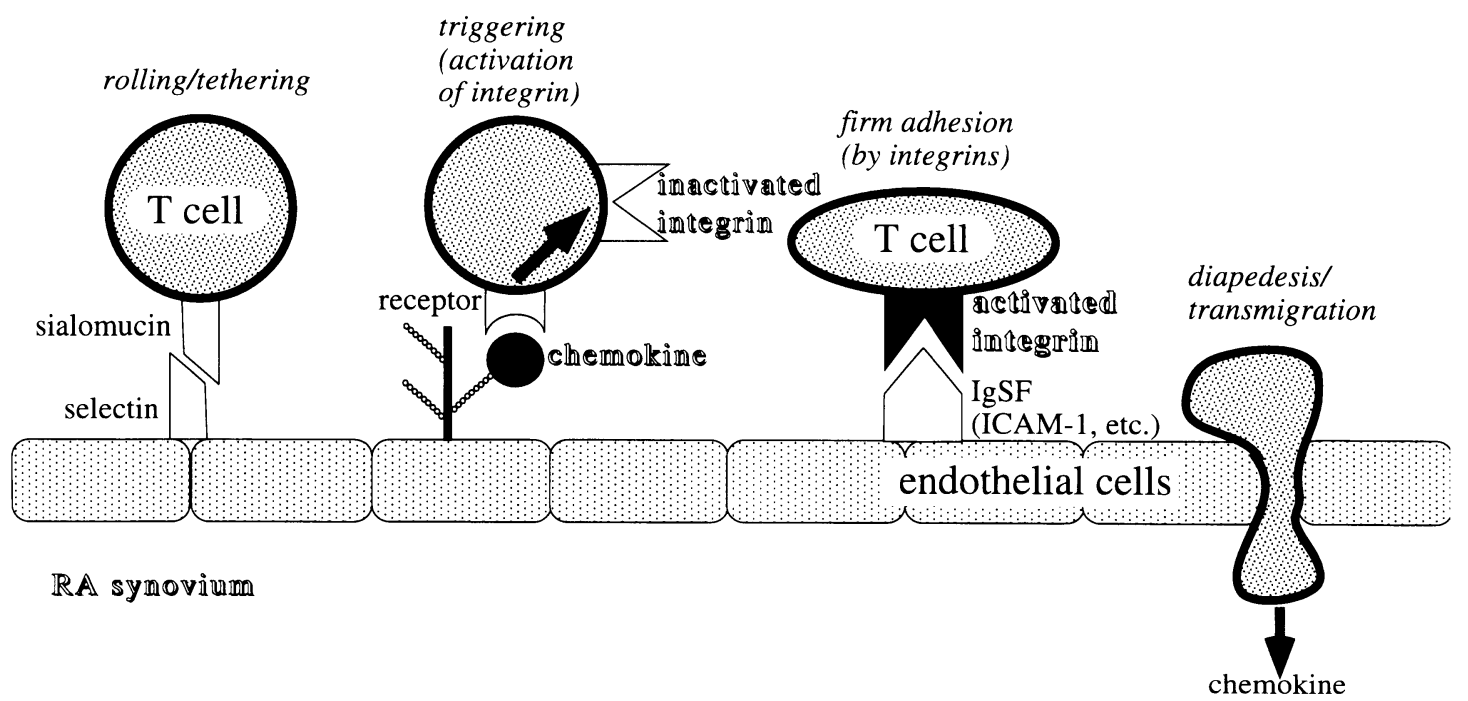

図 $1 \mathrm{RA}$ 滑膜炎症部への T 細胞の遊出におけるケモカインによるインテグリンの活性化とイン テグリン依存性接着の誘導機構

ス）は肥大して疼痛を伴う著しい炎症所見を呈し， パンヌスの進展に伴い軟骨・骨吸収と関節破壊が 認められ，日常生活動作が制限される。

RA はまた, 代表的な自己免疫疾患である. 滑膜 炎症部に集積する $\mathrm{T}$ 細胞の大部分は, 抗原感作を 受けたメモリーT 細胞であり, 特定の自己反応性 クロナリティを有する T 細胞は RA の病因とし ての意義を有する ${ }^{1)}$. RA 滑膜炎組織で認められる $\mathrm{T}$ 細胞の集積は, $\mathrm{T}$ 細胞が組織内へ大量に遊出し た結果である。筆者らは， T 細胞がどのような機 構で末梢循環血中から滑膜組織内遊出するか, 滑 膜組織内で滑膜細胞といかに相互作用を及ぼし合 うかについて，特にケモカインと細胞接着分子の 調節機構(クロストーク)に注目して検討を重ねて きた2).

\section{T 細胞の血管内から RA 滑膜組織への遊出の 機構}

末佾血管内を循環する $\mathrm{T}$ 細胞は, 主に後毛細管 細静脈の血管内皮細胞との間で接着のステップ (接着カスケード)を経て組織へ遊出する(図 1) ${ }^{3)}$. 循環血中の $\mathrm{T}$ 細胞はセレクチンのレクチン 様ドメインとシアロムチンの糖鎖との接触により
ブレーキがかかり一時的に血管内腔にとどまる (tethering)。これは,一時的な on-off の速い接触 にすぎず， T 細胞のインテグリンは，ケモカイン などによって血管内腔に tetherする瞬時に活性 化されて接着性を獲得する(triggering)。その結 果, T細胞の LFA-1 や VLA-4 などのインテグ リンファミリーに属する接着分子と内皮細胞上の ICAM-1 や VCAM-1 などの免疫グロブリンスー パーファミリー $(\mathrm{IgSF})$ に属する接着分子との結 合により接着が完成する(adhesion)。接着した T 細胞は CD 31 や ICAM-1 などの分子の関与によ り内皮細胞間陌を移行して血管外へ遊出する (transmigration).かような接着カスケードは, 好 中球，好酸球，単球と内皮細胞との接着や血小板 の内皮上での凝集などにおいても適応される.

RA 滑膜炎症組織では, 主に滑膜細胞から IL-1 や TNF- $\alpha$ などの炎症性サイトカインが大量に 産生され, 内皮細胞上の接着分子 ICAM-1, VCAM-1, E-セレクチンの発現は, これらのサイ トカイン刺激により伝達される細胞内シグナルに より誘導・増強される。その結果, 循環血中の $\mathrm{T}$ 細胞との接着の機会が増えることにより炎症部へ の浸潤が効率よくもたらされる4). 
(A) soluble form

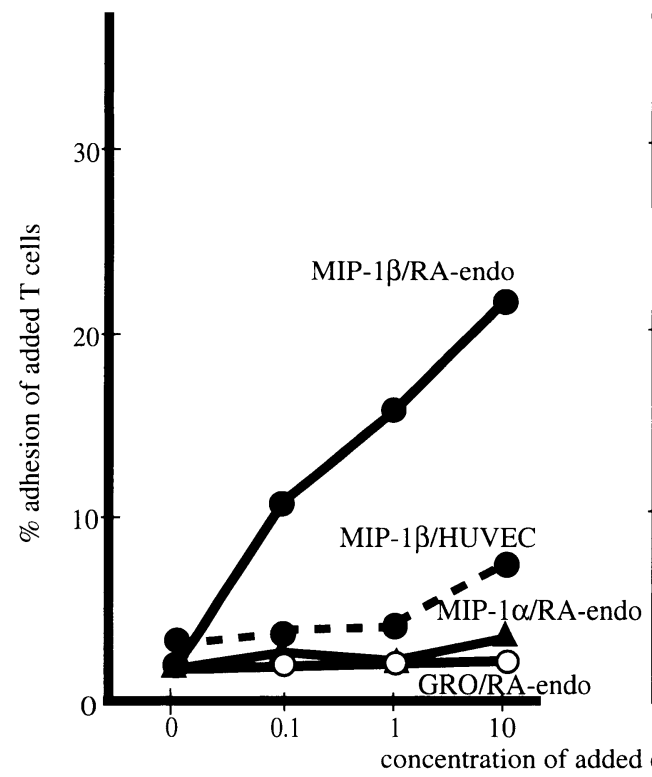

(B) endothelium-immobilized form

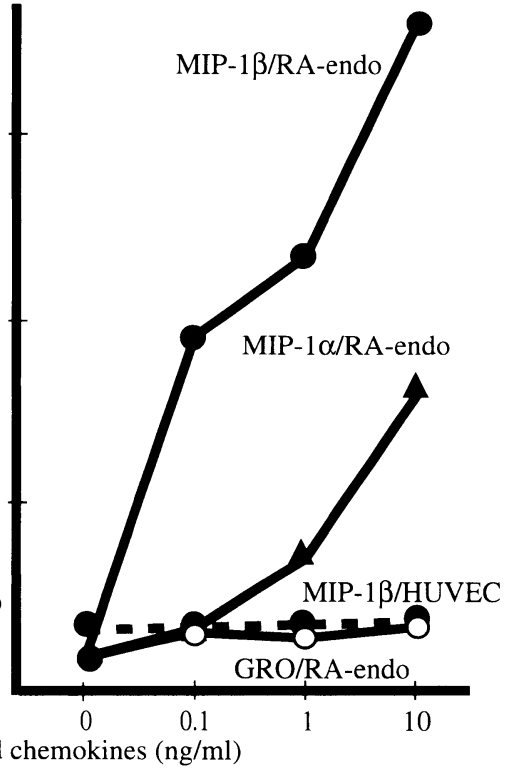

図 2 ケモカインによる $\mathrm{T}$ 細胞と RA 滑膜由来血管内皮細胞とのインテグリ ン依存性接着の誘導

一方， $\mathrm{T}$ 細胞と血管内皮細胞との接着機構にお いて中心的役割を担う $\mathrm{T}$ 細胞のインテグリンは, 活性化されないと接着できない占，筆者らは， RA 滑膜より血管内皮細胞を抽出し, $\mathrm{T}$ 細胞との接着 を検討したところ，T細胞は無刺激下では内皮細 胞と接着できないが， T 細胞インテグリンに選択 的に接着性を誘導するケモカイン macrophage inflammatory protein (MIP) $-1 \alpha$ と MIP-1 $\beta$ を 添加すると高率に接着した (図 2)。その過程にお いて以下の三つの点を明らかにした2)。第一に, $\mathrm{RA}$ 滑膜炎組織より抽出した $\mathrm{T}$ 細胞は, 無刺激下 でケモカイン MIP-1 $\alpha$ と MIP-1 $\beta$ を産生する ことを認めた．第二に，MIP-1 $\alpha$ と MIP-1 $\beta$ は, 短時間内に $\mathrm{T}$ 細胞のインテグリンを活性化し, $\mathrm{G}$ 蛋白質依存性 phosphoinositide 3 キナーゼ (PI 3 K) および, 細胞内骨格依存性のインテグリンの重 合化や立体構造の変化が活性化に関与した，第三 に, RA 滑膜細胞より抽出した血管内皮細胞は, 臍 帯などから得られたものと異なり, へパラン硫酸 プロテオグリカンを特幑的に高発現することが観 察され， $\mathrm{T}$ 細胞と $\mathrm{RA}$ 滑膜由来血管内皮細胞との 接着は, $\mathrm{MIP}-1 \alpha$ と MIP-1 $\beta$ を内皮細胞上のへ
パラン硫酸に固相することにより効率的に誘導さ れることを接着実験で認めた. 免疫組織所見でも， MIP-1 $\alpha$ と MIP-1 $\beta$, および, ペラン硫酸が滑 膜組織内の微小血管に高発現することが確認され た。

\section{ケモカインによるインテグリンの活性化機構}

インテグリンは， $\alpha \beta$ 鎖から構成される膜通過 型糖蛋白質で, 赤血球以外の細胞の膜表面に発現 し, ICAM-1 や VCAM-1 などの細胞膜上の IgSF 分子，およびフィブロネクチンやラミニンなどの 細胞外基質に対する主要なレセプターである。 ンテグリンは，2 価金属陽イオン依存性にリガン ドと接着するが，その接着性は細胞内情報により 制御される。すなわち，インテグリンは発現する だけでは接着できず，インテグリンを介する細胞 接着性の誘導においては, 細胞内の刺激によって インテグリンが活性化されることが必須である. インテグリンのもつとも強力な活性化分子とし て，C-キナーゼを活性化する phorbol myristate acetate (PMA) や細胞内 $\mathrm{Ca}^{2+}$ レベルを上昇させ るCaイオノフォアがあげられる(表 1). 細胞表面 
表 1 インテグリンの活性化に関与する分子群

\begin{tabular}{|c|c|}
\hline 分子名 & 反応細胞 \\
\hline \multicolumn{2}{|l|}{ 薬理学的物質 } \\
\hline PMA (phorbor myriacetate ester) & すべての白血球 \\
\hline calcimycin & $\mathrm{T}$ 細胞 \\
\hline \multicolumn{2}{|l|}{ 細胞表面機能分子 } \\
\hline CD 3/TCR (T cell receptor) complex & $\mathrm{T}$ 細胞 \\
\hline $\mathrm{CD} 2$ & $\mathrm{~T}$ 細胞, NK 細胞 \\
\hline $\mathrm{CD} 28$ & $\mathrm{~T}$ 細胞 \\
\hline CD 31 (PECAM-1) & $\mathrm{T}$ 細胞, NK 細胞, 単球 \\
\hline CD 19 & B 細胞 \\
\hline surface Ig (immunoglobulin) & $\mathrm{B}$ 細胞 \\
\hline$\beta_{1}$ integrin ; CD 29 & $\mathrm{~T}$ 細胞, B 細胞, 単球など \\
\hline$\beta_{3}$ integrin $; \mathrm{CD} 61$ & 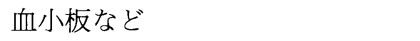 \\
\hline \multicolumn{2}{|l|}{$\alpha(\mathrm{C}-\mathrm{X}-\mathrm{C})$-chemokine } \\
\hline IL-8(interleukin-8) & 好中球, 好塩基球 \\
\hline IP-10 ( $\gamma$-interferon-induced peptide $)$ & 単球, 活性化 $\mathrm{T}$ 細胞 \\
\hline $\mathrm{PF}-4$ (platelet factor-4) & 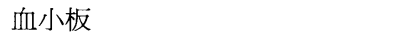 \\
\hline Mig (monokine induced by IFN- $\gamma$ ) & 単球, 活性化 $\mathrm{T}$ 細胞 \\
\hline ENA-78(epithelial-derived neutrophil attractant-78) & 好中球 \\
\hline \multicolumn{2}{|l|}{$\beta(\mathrm{C}-\mathrm{C})$-chemokine } \\
\hline MIP-1 $\alpha$ (macrophage inflammatory protein) & $\mathrm{T}$ 細胞サブセット, 単球 \\
\hline $\mathrm{MIP}-1 \beta$ & $\mathrm{T}$ 細胞サブセット，単球 \\
\hline RANTES (regulated on activation, normal $T$-cell expressed and secreted) & $\mathrm{T}$ 細胞サブセット, 単球, 好酸球 \\
\hline MCP-1,3(monocyte chemotactic protein) & 単球，好塩基球，好酸球 \\
\hline eotaxin & 好酸球 \\
\hline LARC(liver and activation-dependent chemokine) & T 細胞サブセット \\
\hline SLC (secondary lymphoid-tissue chemokine) & T 細胞サブセット \\
\hline \multicolumn{2}{|l|}{$\mathrm{CX}_{3} \mathrm{C}$-chemokine } \\
\hline FKN (fractalkine) & $\mathrm{T}$ 細胞, 単球, $\mathrm{NK}$ 細胞 \\
\hline \multicolumn{2}{|l|}{ 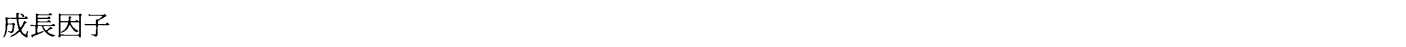 } \\
\hline SCF (stem cell factor, c-Kit ligand) & マスト細胞 \\
\hline HGF (hepatocyte growth factor, c-Met ligand) & T 細胞サブセット \\
\hline \multicolumn{2}{|l|}{ 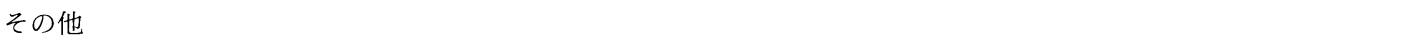 } \\
\hline fMLP(N-formyl-methionyl-leucyl-phenylalanine) & 好中球, 単球, 好酸球, 好塩基球 \\
\hline thrombin & 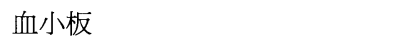 \\
\hline C 5 a (fifth complement component) & 好中球 \\
\hline oxidized LDL(low density lipoprotein) & 単球 \\
\hline PAF (platelet-activating factor) & 血小板, 単球, 好中球, 好酸球 \\
\hline
\end{tabular}

の CD 3/TCR 複合体, CD 28, CD 31，インテグリ ンなどを介する刺激もインテグリンを活性化す $3^{5,6)}$. 筆者らは, MIP-1 $\beta$ や MIP-1 $\alpha$ などのケモ カイン刺激によってもインテグリンが活性化され ることを報告した ${ }^{7)}$.

ケモカインは, 細胞遊走活性 (chemotaxis) を有 する cytokine として命名され，IL-8 に代表され る $\alpha(\mathrm{CXC})$ ファミリー, $\mathrm{MIP}-1$ な どの $\beta(\mathrm{CC})$ ファミリー, 膜結合型の fractalkine $\left(\mathrm{CX}_{3} \mathrm{C}\right)$ に分
類される 50 以上のサイトカインを含むファミ リーの総称である ${ }^{8)}$. ケモカインは, 以下のような 多彩な特性を有するサイトカインである. (1) 大部 分のケモカインは，静止期細胞や正常組織からは ほとんど産生されないが，炎症部やリンパ組織の 活性化 $\mathrm{T}$ 細胞やマクロファージから大量に産生 され，炎症病態形成に中心的に関与する。 (2) 生物 活性として走化性のみならず，インテグリンの活 性化を介する細胞接着の誘導能, リゾチームや活 


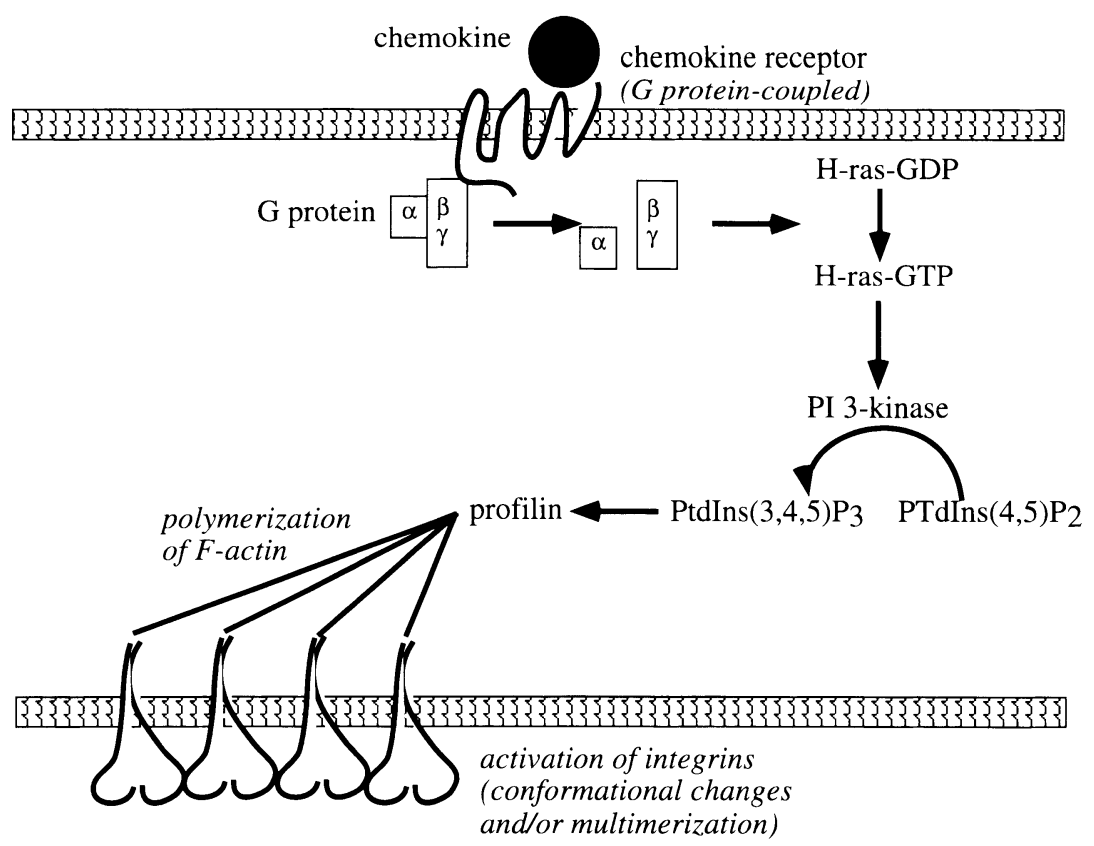

図 3 ケモカインによるインテグリンの活性化情報伝達機構：情報伝達蛋白質, 細胞質内蛋白質と細胞内骨格の役割

性酸素の産生能などを有す. (3) 標的細胞は,レセ プターの発現様式に基づくサブセット特異性があ る. (4)レセプターは多彩だが, いずれも $G$ 蛋白質 結合性レセプターファミリーに属し，細胞内情報 伝達に直接関与する. (5) ヘパリン結合部を介して ヘパラン硫酸プロテオグリカンと結合する. (6) ケ モカイン，そのレセプターとも HIV 感染と緊密 な関連性がある。

\section{インテグリン活性化の情報伝達機構}

In vitro では, PMA や MIP-1 $\beta$ 刺激によって 伝達される細胞内シグナルは，インテグリンの発 現量を変えずに，T細胞のインテグリンを活性化 し, ICAM-1 や VCAM-1 への接着を 15 分以内に 誘導する7). ケモカインを含む遊走活性因子のレ セプターの多くは七つの細胞膜通過部位を有する $\mathrm{G}$ 蛋白質共役型 “serpentine”レセプターファミ リーに属し，これらの遊走活性因子はレセプター に結合することによって，会合する G 蛋白質をり ン酸化し, phospholipase C (PLC) - $\beta 2$ の活性化 などを介して，PI 3 K を会合して活性化シグナル を伝達する ${ }^{9)}$. 実際, MIP- $1 \alpha$ や MIP-1 $\beta$ 刺激に
よって誘導される $\mathrm{T}$ 細胞の血管内皮細胞上のリ ガンドとのインテグリン依存性の接着は，非共役 型 $\mathrm{G}$ 蛋白質である百日咳毒素や PI 3 K 阻害剤で ある wortmannin や LY 294002 で細胞を処理す ると減弱する ${ }^{10)}$.

インテグリンの活性化は，インテグリンの細胞 内ドメインに会合する細胞内骨格蛋白質に依存性 のインテリンの細胞外立体構造の変化による affinity の増強, 多量体化による avidity の増強, 両者が組み合わさった clusteringによって誘導 される11)、インテグリンの多量体化や細胞外立体 構造の変化には, 細胞内骨格蛋白質である Factin が重合化することが必要とされる，MIP-1 $\alpha$ や MIP-1 $\beta$ は，T細胞インテグリンの細胞内

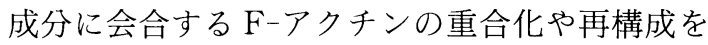
30 秒以内に引き起こし，インテグリンを活性化し 内皮細胞との接着を誘導する ${ }^{10)}$. F-アクチンの重 合化は，プロフィリンなどの細胞質内蛋白質が ADP-アクチンを ATP-アクチンに変換すること によってもたらされる。

最近, プロフィリンが PIP $\mathrm{P}_{2}$ や PI $3 \mathrm{~K}$ と会合し, 情報伝達にも関与することが報告された。筆者ら 
表 2 ケモカインとケモカインレセプター

\begin{tabular}{|c|c|c|}
\hline レセプター & ケモカイン & レセプターの主な発現細胞 \\
\hline CCR 1 & MIP-1 $\alpha$, RANTES, HCC $1 \sim 4$ & 単球, $\mathrm{T}$ 細胞 \\
\hline $\operatorname{CCR} 2 \mathrm{a}, \mathrm{b}$ & $\mathrm{MCP}-1 \sim 4$ & 単球, $\mathrm{T}$ 細胞，好塩基球， $\mathrm{NK}$ 細胞 \\
\hline CCR 3 & eotaxin $1 \sim 3$, RANTES, MCP-3 & 好酸球，好塩基球，Th 2 細胞 \\
\hline CCR 4 & TARC, MDC & T 細胞, NK 細胞, 樹状細胞 \\
\hline CCR 5 & RANTES, MIP- $1 \alpha$, MIP $-1 \beta$ & 単球, $\mathrm{T}$ 細胞, 樹状細胞, $\mathrm{Th} 1$ 細胞 \\
\hline CCR 6 & MIP-3 $\alpha$, LARC & T 細胞, 樹状細胞 \\
\hline CCR 7 & MIP-3 $\beta$, ELC, TCA-4 & $\mathrm{T}$ 細胞, 単球, 樹状細胞 \\
\hline CCR 8 & TARC, I 309 & Th 2/Tc 2 細胞, 単球 \\
\hline CCR 9 & TECK & \\
\hline CXCR 1 & IL-8, GCP-2 & 好中球 \\
\hline CXCR 2 & IL-8, GRO, NAP-2, ENA-78 & 好中球, NK 細胞 \\
\hline CXCR 3 & IP-10, Mig, ITAC & Th 1/Tc 1 細胞 \\
\hline CXCR 4 & $\mathrm{SDF}-1 \alpha, \beta$ & 白血球全般？ \\
\hline CXCR 5 & $\mathrm{BCA}-1$ & B 細胞 \\
\hline $\mathrm{XCR} 1$ & lymphotactin, SCM-1 $\alpha$ & \\
\hline $\mathrm{XCR} 2$ & $\mathrm{SCM}-1 \beta$ & \\
\hline CX 3 CR 1 & FKN & 単球, $\mathrm{NK}$ 細胞, $\mathrm{T}$ 細胞 \\
\hline
\end{tabular}

は, T細胞において，プロフィリンと重合化した F-アクチンとの局在が一致すること, 百日咳毒素 や wortmannin で前処理すると，プロフィリンが 分散して F-アクチンの重合化が阻害されること を認めた ${ }^{10)}$.さらに, $\mathrm{T}$ 細胞や $\mathrm{B}$ 細胞において, ケモカイン刺激や低分子量 GTPase ファミリー 分子である H-Ras の遺伝子導入により PI $3 \mathrm{~K}$ の活性化を介してプロフィリン依存性の骨格線維 アクチンの重合化がもたらされ, LFA-1 が NKIL 16 抗体で認識される接着可能な活性エピトー プへ変換され，リガンドや血管内皮細胞とのイン テグリン依存性の接着親和性が誘導されること, ケモカイン刺激により常時インテグリンが活性化 されている $\mathrm{T}$ 細胞性白血病細胞に, $\mathrm{H}-\mathrm{Ras} の$ dominant negative 変異体を遺伝子導入すると, プロフィリンを介したアクチンの重合化やインテ グリンの活性化が抑制されることを認め た ${ }^{10,12,13)}$ ．他施設からも R-Ras，H-Ras， Rho A などの低分子量 $\mathrm{G}$ 蛋白質がインテグリン接着性

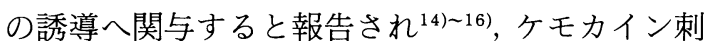
激を介するシグナルは，これらの低分子量 $\mathrm{G}$ 蛋白 質依存性の PI $3 \mathrm{~K}$ の活性化とそれに引き続くプ ロフィリンによる F-アクチンの重合化を誘導し, インテグリン依存性の接着を誘導するものと思わ
れる(図 3)。

\section{ケモカインの资症病態形成における意義}

MIP-1 $\alpha$ や MIP-1 $\beta$ による T 細胞のインテ グリン活性化の報告につづき，ケモカインの多く は，遊走活性以外にもインテグリンの活性化を介 する細胞接着の誘導機能を有することが明らかと なった. Regulated upon activation, normal T cell expressed and secreted(RANTES) や fractalkine(FKN) はメモリーT 細胞に, secondary lymphoid-tissue chemokine(SLC) は CCR 7 をへしてナイーブ T 細胞に, monocyte chemotactic protein (MCP)-1 は単球に, interleukin(IL)-8 は好中球に, FKN は NK 細胞に, platelet factor $(\mathrm{PF})-4$ は血小板にインテグリン の活性化と内皮細胞との接着や凝集を誘導す $ろ^{4)}$.

なぜ $\mathrm{T}$ 細胞が炎症部へ集積しうるかを考える 際， T 細胞上のインテグリンの接着性の誘導は重 要な意味を有する．インテグリンに活性化が不要 とするならば，T 細胞は正常組織内へつぎつぎと 非選択的に遊出してしまうはずである。前述のよ うに，大部分のケモインは静止期の細胞や正常組 織からは産生されないが, 特に炎症部に存在する 
活性化リンパ球などから大量に産生される，炎症 部で大量に産生されたケモカインによる循環血中 の $\mathrm{T}$ 細胞のインテグリンの活性化と, 内皮細胞と の接着，それに引き続く組織内への遊出を効率的 に誘導することによって炎症形成と重要な関連性 を有する。もちろん，このようなケモカイン刺激 によるインテグリン依存性の細胞接着の誘導は, $\mathrm{T}$ 細胞などの白血球と抗原提示細胞，上皮細胞， 間質細胞，滑膜細胞，平滑筋細胞など，組織内の その周囲に存在する細胞や細胞外基質との接着の 機構においても必要である。

ケモカインの細胞遊走活性やインテグリンの活 性化機能は, レセプターの発現様式の相違に基づ く白血球のサブセット特異性を有し，特定の炎症 組織に特定の炎症性細胞を集積させて特異的炎症 を誘導する際にケモカインは key roleを担う(表 2)。たとえば，炎症早期部では IL-8 が産生されて まず好中球が内皮細胞と接着して浸潤する。 RA 患者の滑膜組織中の $\mathrm{T}$ 細胞などから産生される MIP-1 $\alpha$, MIP-1 $\beta$ や RANTES は T 細胞の滑 膜組織内への集積をもたらすが，滑液中には IL-8 が大量に認められむしろ好中球が検出される2). 実際, 滑膜組織内の T 細胞は, ケモカインレセプ ターのなかでCCR 5 をもっとも高発現する ${ }^{17,18)}$. また，アレルギー性炎症部では eotaxin や $\mathrm{MCP}-$ 3 が産生された結果これらに対するレセプター CCR 3 を発現する好酸球が集積し，動脈硬化性炎 症部や糸球体腎炎組織では $\mathrm{MCP}-1$ が単球の接着 を誘導し同部位へ浸潤させる ${ }^{19)}$.

\section{ケモカインの機能発現におけるへパラン硫酸プ ロテオグリカンの役割}

滑膜炎組織内より産生されたケモカインは，血 管内の $\mathrm{T}$ 細胞上のインテグリン依存性の接着を 誘導するが，生体内では，血管内腔に放出された ケモカインのような液性因子は血流により即時に 流出されるはずであり，作用するに十分濃度が血 管内腔に存在しうるかという疑問が生じる。 ケモ カインは，へパリン結合性サイトカインで，in vivo では細胞表面や細胞外基質のへパラン硫酸 プロテオグリカンと結合しうる。ペラン硫酸プ
ロテオグリカンはコア蛋白質とそれに結合する二 糖類の連鎖するへパラン硫酸側鎖よりなる分子群 である、へパラン硫酸プロテオグリカンは，へパ リン結合性サイトカインを結合することによって 以下のよういくつかの利点をサイトカインに提供 する. (1) サイトカインを炎症部の血管内皮細胞上 や転移性癌細胞上などの必要な特定部位に集積さ せることができる. (2) サイトカインに活性型立体 構造を誘導する. (3) 血流によるずれ応力などの物 理的刺激や組織内での消化酵素による分解などの 化学的刺激から保護する. (4) サイトカインのみな らずそのレセプターなどの細胞表面分子と結合し て，より強い情報伝達を可能とする立体構造を形 成しうる 20,21 .

ヘパラン硫酸プロテオグリカンは, 上皮系の細 胞に発現するとされるが，炎症部の血管内皮細胞 においても発現し，RA 患者の滑膜炎組織などの 炎症部の血管内皮細胞上には大量に発現する。し かし，血管内皮細胞の実験で汎用する臍帯静脈由 来内皮細胞には全く発現しない2 ${ }^{21}$. In vitro では, $\mathrm{T}$ 細胞と RA 滑膜由来血管内皮細胞との接着は, MIP-1 $\alpha$ と MIP-1 $\beta$ を内皮細胞上に固相化した 際にはより強い接着が観察され，その接着は，内 皮細胞をあらかじめへパリチナーゼなどで酵素処 理すると，認められなくなる。また，これらのケ モカインは, リンパ節, 扁桃組織や RA 患者滑膜 の内皮細胞上に免疫組織染色により検出される. すなわち, ヘパラン硫酸プロテオグリカンは, ケ モカインを固相(配置)し，血流により流出される ことなく必要個所に集積させうる。その結果, ケ モカインは内皮細胞上に tether する $\mathrm{T}$ 細胞のレ セプターに提示(転送)され，T細胞インテグリン を活性化し内皮細胞との接着を効率よく誘導す る。また，その結合は特異的であり，特定の場所 で特定のケモカインに機能発現をもたらす ${ }^{20)}$. こ のような細胞接着を介して発揮されるサイトカイ ンの機能は, juxtacrine とよばれる(図 4).以上, サイトカインは，本来流動性と拡散性を特性とす るが，ヘパラン硫酸プロテオグリカンに結合する ことによって，必要個所に高濃度に集積し，また， 物理的・化学的刺激から保護されて, より効率的 


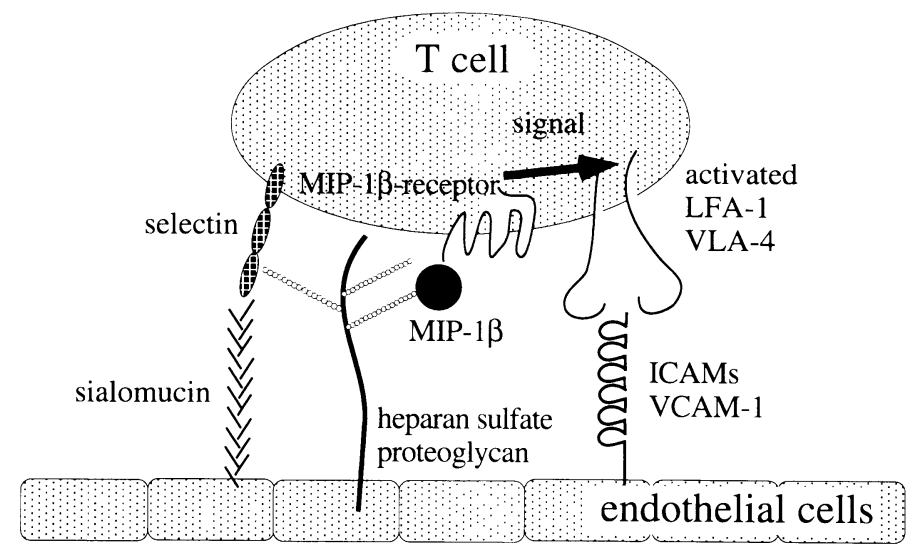

図 4 ケモカインによるjuxtacrine $\mathrm{T}$ 細胞インテグリン刺 激機構における RA 滑膜血管内皮細胞上のへパラン 硫酸プロテオグリカンの介在

に機能が誘導されうる.

\section{T 細胞や RA 滑膜細胞における細胞接着を介す \\ るサイトカイン産生誘導機構}

滑膜炎組織内では，T 細胞はマクロファージな どの抗原提示細胞や活性化された滑膜細胞に発現 する MHC class II分子上に提示される抗原情報 を T 細胞レセプターを介して認識する。この際, 抗原情報(主刺激) とともに, LFA-1 などのインテ グリンや CD 28 などを介する副刺激 (costimulation)の共存が必須であり, 両刺激の共存により T 細胞は活性化される. In vitro で CD 3 抗体と ICAM-1 の双方を固相化すると, T 細胞の増殖や IL-2 産生が著明に誘導される ${ }^{22)}$. RA 滑膜細胞に は, ICAM-1 を強く発現し T 細胞に対して stimulator としてと同時に responder としても機能 する線維芽細胞様滑膜細胞が多く認められるとさ れる. 実際, 滑膜細胞上の ICAM-1 は, T 細胞と の細胞接着のみならず，インテグリンを介して副 刺激を伝達する分子としても機能する。また, LFA-1/ICAM-1の接着経路を介して, CD 28/ CD 86 非依存性に, IFN- $\gamma$ のみならず MIP-1 $\alpha$, MIP-1 $\beta$, RANTES などのケモカインの産生を T 細胞に誘導できる ${ }^{23)}$. 逆に, costimulation シグ ナル伝達を阻害すると T 細胞は活性化されずに 免疫学的寛容状態,さらにアポトーシスに陥る ${ }^{24)}$. 実際, CD 28 をノックアウトしたマウスでは, T 細
胞は TCR/CD 3 複合体や他の costimulation シ グナル伝達分子を反復刺激しても反応せず，また， コラーゲン誘導関節炎を起こさない25).

$\mathrm{RA}$ と変形性関節症 $(\mathrm{OA})$ の滑膜組織を比較す ると, RA 滑膜組織では, 血管内皮細胞と滑膜表層 から表層下の滑膜細胞が抗 ICAM-1 抗体で強染 色される. 滑膜細胞に発現する ICAM-1を特異抗 体で架橋形成すると, 転写因子 AP-1 の活性化を 介して IL-1 $\beta$ 遺伝子の転写を誘導する ${ }^{26)}$. また, $\mathrm{OA}$ と比較すると, RA 滑膜においてヒアルロン 酸レセプターとして知られるCD 44 の発現が著 明に増強し, その発現は炎症強度に相関して観察 される. RA 滑膜細胞では, CD 44 を特異抗体や細 胞外基質蛋白質で架橋形成すると, 転写因子 AP1 の活性化を介して IL-1 $\beta$ や ICAM-1や VCAM-1の遺伝子の転写が誘導される ${ }^{27,28)}$.ま た，マクロファージなどに発現する CD 40 は, T 細胞の CD $40 \mathrm{~L}$ と接着して, チロシンキナーゼ依 存性の MAP/ERK キナーゼの活性化を誘導し, IL-1や TNF- $\alpha$ などの炎症性サイトカインの産 生をもたらす。また, この情報伝達は, マクロ ファージをあらかじめ IL-4 や IL-10 で処理する と抑制される ${ }^{29)}$. すなわち, 滑膜細胞に発現する ICAM-1 や CD 44 は, 細胞接着を介して細胞外情 報を細胞内に伝達する役割を担い, サイトカイン 産生などの細胞機能をも誘導することが明らかで ある。 


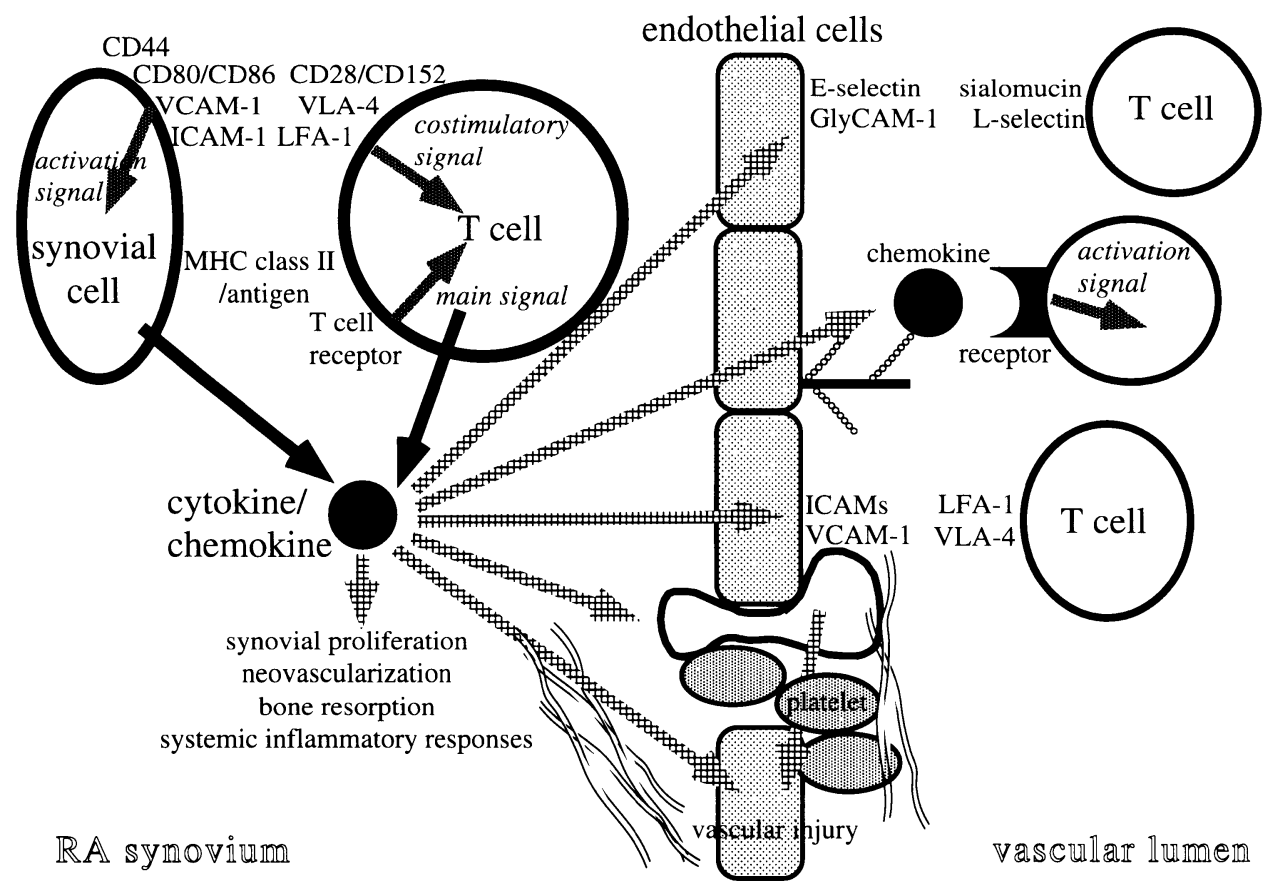

図 5 滑膜炎症病態に扔けるサイトカインと接着分子のクロストーク

\section{RA 滑膜炎病態形成における接着分子とケモカ インのクロストーク}

RA 滑膜炎症部では，T 細胞は組織内から産生 されるケモカイン刺激によって伝達される細胞内 シグナルによりインテグリンが活性化されて接着 可能となり, 組織内へ遊出すること, ケモカイン が効率的に機能するためには滑膜炎症部の血管内 皮細胞に発現するへパラン硫酸プロテオグリカン が介在することが解明されたＩCAM-1や VCAM-1 の発現も，IL-1 などのサイトカイン刺 激によって伝達される細胞内シグナルにより誘導 される。すすなお，接着分子の発現量やインテグ リンの接着性は，サイトカインなどの刺激によっ て伝達される細胞内シグナルにより調節される (inside-out signal). 逆に, $\mathrm{T}$ 細胞を抗原刺激する 際の costimulatory シグナルや滑膜細胞に発現す る ICAM-1 やCD 44 を介するシグナルは，細胞 接着を介して細胞外情報を細胞内に伝達し, 細胞 の活性化やサイトカイン産生を誘導する (outside-in signal). 以上のように, サイトカインと接 着分子は, 2 方向のシグナルを介して互いに制御・
協調 (クロストーク)し，細胞間の相互作用を調節 する.かような接着分子をめぐる二方向のシグナ ル伝達機構は， RA 滑膜炎の病態形成やその遷延 化において最大限に発揮されるが, ケモカインの 産生, インテグリンの活性化やへパラン硫酸プロ テオグリカンの発現は, 炎症, 凝固, 腫瘍などな んらかの病態と関連してより効率的にもたらされ るものである(図 5)。また，これらの概念は，RA のみならず自己免疫, 感染, アレルギー, 癌細胞 浸潤, 移植拒絶, 動脈硬化などを契機にもたらさ れる炎症病態をはじめとするさまざまな病態の解 明に結びつくものと期待される.

\section{治療的応用への展望}

接着分子とケモカインとのクロストークという 観点から，RAの治療戦略を考えると，(1) insideout signal の観点から接着分子の発現量や接着性 を誘導するサイトカインやケモカイン刺激に対す る療法, (2) 誘導された接着分子を介する接着阻 害, (3) outside-in signaling に関与する接着分子 (細胞表面機能分子)の阻害などがあげられる．接 
着分子阻害の臨床応用は, RA 患者に対する ICAM-1 抗体の投与で一定の効果は報告され，マ ウス関節炎モデルで，LFA-1/ICAM-1 抗体, VLA-4 坑体, CD 40 L 抗体, CTLA-4-Ig キメラ の投与による病態制御が報告される。また，動物 関節炎モデルでは，抗 RANTES 抗体，抗 MIP-1 $\alpha$ 抗体, 抗 MCP-1 抗体などのケモカイン抗体の 投与が発症の遅延や病態の制御に有効であ $3^{30,31)}$. 抗炎症性サイトカインである IL-1 レセプ ターアンタゴニスト, 可溶性 TNFレセプター, IL-4，IL-10，IL-13 などの遺伝子を種々のべク ターを用いて関節局所，または全身投与して遺伝 子導入し，動物関節炎の制御において良好な成績 が得られている ${ }^{32)}$.さらに，可溶性 TNFレセプ ター (etanercept, p 75 と Fc の合成蛋白質) は, 米 国ではすでに FDA で認可されているが33)，これ らの抗サイトカイン療法は, inside-out signal の 制御という観点からもとらえることができる。将 来的には，アデノウイルスなどのベクターを用い た接着分子や上記情報伝達関連分子の遺伝子療 法，また，抗接着分子抗体とサイトカイン遺伝子 ベクター複合体イムノジーンの使用など，接着分 子へのアプローチも治療の新機軸の一つとして期 待される。いかに炎症を特異的にかつ効率よく抑 制しうるかは長年の課題であるが，ケモカインと レセプター発現やインテグリンの活性化などを制 御することによって，より選択的，かつ，効率的 な疾患制御への道が開けるものと期待される.

\section{文 献}

1) Feldmann M, Brennan FM, Maini RN : Rheumatoid arthritis. Cell $85: 307-312,1996$.

2) Tanaka $Y$, Fujii K, Hubscher S et al. : Heparan sulfate proteoglycan on endothelium efficiently induces integrin-mediated $\mathrm{T}$ cell adhesion by immobilizing chemokines in rheumatoid synovitis. Arthritis Rheum $41: 1365-1377,1998$.

3) Shimizu Y, Newman W, Tanaka Y et al. : Lymphocyte interactions with endothelial cells. Immunol Today 13:106-112, 1992.

4) Springer $T A$ : Traffic signals on endothelium for lymphocyte recirculation and leukocyte emigration. Annu Rev Physiol 57:827-872, 1995.

5) Tanaka Y, Albelda SM, Horgan KJ et al. : CD 31 expressed on distinctive $T$ cell subsets is a preferential amplifier of $\beta 1$ integrin-mediated adhesion. J
Exp Med $176: 245-253,1992$.

6) Zell T, III SWH, Mobley JL et al. : CD 28-mediated up-regulation of $\beta$-integrin adhesion involves phosphatidylinositol 3-kinase. J Immunol 156 : 883891, 1996.

7) Tanaka Y, Adams DH, Hubscher S et al. : T-cell adhesion induced by proteoglycan-immobilized cytokine MIP-1 $\beta$. Nature 361:79-82, 1993.

8) Homey B, Zlotnik A : Chemokines in allergy. Curr Opi Immunol 11:626-634, 1999.

9) Shimizu Y, Hunt III SW : Regulating integrinmediated adhesion : one more function for PI 3kinase? Immunol Today 17:565-573, 1996.

10) Tanaka $Y$, Minami $Y$, Mine $S$ et al. : H-Ras signals to cytoskeletal machinery in induction of integrinmediated adhesion of $\mathrm{T}$ cells. J Immunol 163: 6209-6216, 1999.

11) Binnerts M, van Kooyk $Y$ : How LFA-1 binds to different ligands. Immunol Today $20: 240-245$, 1999.

12) Tanaka Y : Activation of leukocyte funciton-associated antigen-1 on adult T-cell leukemia cells. Leuk Lymphoma 163:6209-6216, 1999.

13) Liu $Z$-J, Tanaka $Y$, Fujimoto $H$ et al. : A novel role for $\mathrm{H}-\mathrm{Ras}$ in the regulation of VLA-4 integrin and VCAM-1 via c-Myc-dependent and -independent mechanisms. J Immunol $163:$ 4901-4908, 1999.

14) Shibayama H, Anzai N, Braun SE et al. : H-Ras is involved in the inside-out signaling pathway of interleukin-3-induced integrin activation. Blood 93:1540-1548, 1999.

15) Zhang $Z$, Vuori $\mathrm{K}$, Wang $\mathrm{H}$ et al. : Integrin activation by R-ras. Cell $85: 61-68,1996$.

16) Laudanna C, Campbell JJ, Butcher EC: Role of Rho in chemoattractant-activated leukocyte adhesion through integrins. Science 271:981-983, 1996.

17) Mack M, Bruhl H, Gruber R et al. : Predominance of mononuclear cells expressing the chemokine receptor CCR 5 in synovial effusions of patients with different forms of arthritis. Arthritis Rheum 42: 981-988, 1999.

18) Gomez RJ, Pablos JL, Carreira PE et al. : Association of rheumatoid arthritis with a functional chemokine receptor, CCR 5. Arthritis Rheum 42: 989-992, 1999.

19) Kitayama J, Mackay CR, Ponath PD et al. : The CC chemokine receptor CCR 3 participates in stimulation of eosinophil arrest on inflammatory endothelium in shear flow. J Clin Invest $101: 2017-2024$, 1998.

20) Tanaka Y, Kimata K, Adams DH et al. : Modulation of cytokine function by heparan sulfate proteoglycans : sophisticated models for the regulation of cellular responses to cytokines. Proc Assoc Am Physicians 110: 118-125, 1998.

21) Tanaka Y, Adams DH, Shaw S : Proteoglycans on endothelial cells present adhesion-inducing cytokines to leukocytes. Immunol Today $14: 111-115$, 1993.

22) Chen T, Goldstein JS, O'Boyle K et al. : ICAM-1 co-stimulation has differential effects on the acti- 
vation of $\mathrm{CD}^{+}$and $\mathrm{CD} 8^{+} \mathrm{T}$ cell. Eur $\mathrm{J}$ Immunol $29: 809-814,1999$.

23) Kim JJ, Tsai A, Nottingham LK et al. : Intracellular adhesion molecule- 1 modulates $\beta$-chemokines and directly costimulates $\mathrm{T}$ cells in vivo. $\mathrm{J}$ Clin Invest $103: 869-877,1999$.

24) Schwarz RH : Models of $T$ cell anergy : is there a common molecular mechanism? J Exp Med 184 : 1-10, 1996.

25) Tada Y, Nagasawa K, Ho A et al. : CD 28-deficient mice are highly resistant to collagen-induced arthritis. J Immunol 162 : 203-208, 1999.

26) Koyama $Y$, Tanaka $Y$, Saito $K$ et al. : Cross-linking of intercellular adhesion molecule-1(CD 54) induce $\mathrm{AP}-1$ activation and interleukin $-1 \beta$ transcription. J Immunol $157: 5097-5103,1996$.

27) Fujii K, Tanaka $Y$, Hubscher S et al. : Crosslinking of CD 44 on rheumatoid synovial cells upregulates VCAM-1. J Immunol 162:2391-2398, 1999.

28) Fujii K, Tanaka Y, Hubscher S et al. : Crosslinking of $\mathrm{CD} 44$ on rheumatoid synovial cells augment IL6 production. Lab Invest $79: 1439-1446,1999$.

29) Suttles J, Milhorn DM, Miller RW et al. : CD 40 signaling of monocyte inflammatory cytokine synthesis through an ERK $1 / 2$-dependent pathway. A target of interleukin(il) -4 and il-10 anti-inflammatory action. J Biol Chem 274:5835-5842, 1999.

30) Szekanecz Z, Strieter RM, Kunkel SL et al. : Chemokines in rheumatoid arthritis. Springer Semin Immunopathol 20:115-132, 1998.

31) Barnes DA, Tse J, Kaufhold M et al. : Polyclonal antibody directed against human RANTES ameliorates disease in the Lewis rat adjuvant-induced arthritis model. J Clin Invest $101: 2910-2919,1998$.

32) Evans $\mathrm{CH}:$ Gene therapy for rheumatic diseases. Arthritis Rheum 42:1-16, 1999.

33) Goldenberg MM : Etanercept, a novel drug for the treatment of patients with severe, active rheumatoid arthritis. Clin Ther 21:75-87, 1999. 